\title{
Front Matter: Volume 11757
}

, "Front Matter: Volume 11757," Proc. SPIE 11757, Smart Biomedical and Physiological Sensor Technology XVIII, 1175701 (6 May 2021); doi:

$10.1117 / 12.2598681$

SPIE. Event: SPIE Defense + Commercial Sensing, 2021, Online Only 


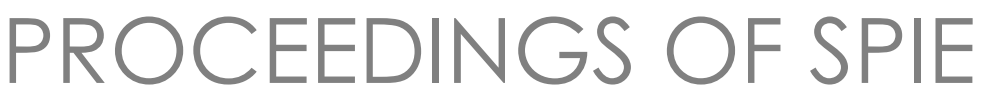

\title{
Smart Biomedical and Physiological Sensor Technology XVIII
}

\author{
Brian M. Cullum \\ Douglas Kiehl \\ Eric S. McLamore \\ Editors
}

12-16 April 2021

Online Only, United States

Sponsored and Published by

SPIE 
The papers in this volume were part of the technical conference cited on the cover and title page. Papers were selected and subject to review by the editors and conference program committee. Some conference presentations may not be available for publication. Additional papers and presentation recordings may be available online in the SPIE Digital Library at SPIEDigitalLibrary.org.

The papers reflect the work and thoughts of the authors and are published herein as submitted. The publisher is not responsible for the validity of the information or for any outcomes resulting from reliance thereon.

Please use the following format to cite material from these proceedings:

Author(s), "Title of Paper," in Smart Biomedical and Physiological Sensor Technology XVIII, edited by Brian M. Cullum, Douglas Kiehl, Eric S. McLamore, Proc. of SPIE 11757, Seven-digit Article CID Number (DD/MM/YYYY); (DOI URL).

ISSN: 0277-786X

ISSN: 1996-756X (electronic)

ISBN: 9781510643512

ISBN: 9781510643529 (electronic)

Published by

SPIE

P.O. Box 10, Bellingham, Washington 98227-0010 USA

Telephone +1 3606763290 (Pacific Time)

SPIE.org

Copyright @ 2021 Society of Photo-Optical Instrumentation Engineers (SPIE).

Copying of material in this book for internal or personal use, or for the internal or personal use of specific clients, beyond the fair use provisions granted by the U.S. Copyright Law is authorized by SPIE subject to payment of fees. To obtain permission to use and share articles in this volume, visit Copyright Clearance Center at copyright.com. Other copying for republication, resale, advertising or promotion, or any form of systematic or multiple reproduction of any material in this book is prohibited except with permission in writing from the publisher.

Printed in the United States of America by Curran Associates, Inc., under license from SPIE.

Publication of record for individual papers is online in the SPIE Digital Library.

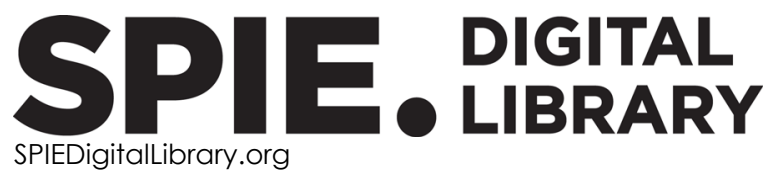

Paper Numbering: A unique citation identifier (CID) number is assigned to each article in the Proceedings of SPIE at the time of publication. Utilization of CIDs allows articles to be fully citable as soon as they are published online, and connects the same identifier to all online and print versions of the publication. SPIE uses a seven-digit CID article numbering system structured as follows:

- The first five digits correspond to the SPIE volume number.

- The last two digits indicate publication order within the volume using a Base 36 numbering system employing both numerals and letters. These two-number sets start with 00, 01, 02, 03, 04, 05, 06, 07, 08, 09, 0A, OB ... 0Z, followed by 10-1Z, 20-2Z, etc. The CID Number appears on each page of the manuscript. 


\section{Contents}

WEARABLE SENSORS I

1175702 Deterioration of textile vs. electronic components over time in athletic wearable devices [11757-1]

1175703 Show me the SO2: real-time LED oximetry display on multimodal wearable devices [11757-2]

1175707 Low-voltage capacitive measurement methodology for dielectric elastomers [11757-6]

1175708 Thin-film nanostructure-based enzymatic alcohol sensor for wearable sensing and monitoring applications [11757-7]

WEARABLE SENSORS II

11757 OD Where the silicone meets the wrist: direct over molding of biometric sensors on a wearable band [11757-12]

\section{SMART DEVICES}

$11757 \mathrm{OE}$ Sensing and removal of chromium metal ion from water using spectroscopic and adsorption techniques [11757-13]

$11757 \mathrm{OF} \quad$ Acoustic steering of audible and ultrasonic waves using THermally-induced Optical Reflection of Sound (THORS) [11757-14]

11757 OG Visualization of photothermal interaction of Bessel beam with gastric tumor based on COMSOL [11757-15]

$11757 \mathrm{OH} \quad$ Miniaturized, wireless multi-channel potentiostat platform for wearable sensing and monitoring applications [11757-16]

$117570 \mathrm{Ol}$ Sensitivity-enhanced localized surface plasmon resonance biosensing format dedicated for point-of-care testing tools [11757-17] 
MEDICAL AND PHYSIOLOGICAL DEVICES

11757 OM Operator state monitoring via pupilometry: measuring mental workload under varying Iuminance conditions [1 1757-21]

$117570 Q \quad$ Implementation of novel TMS coils for multisite brain stimulations [1 1757-25]

MATERIAL DEVELOPMENT AND FUNDAMENTAL STUDIES

11757 OS Design of ZnSe QPM for wide transparency sensing and laser applications [1 1757-26]

11757 OT Studies of microstructure, dielectric behavior of $\mathrm{mg}$-doped and undoped $\left.\mathrm{BCTO}_{\left(\mathrm{Bi}_{2} / 3\right.} \mathrm{CU}_{3} \mathrm{Ti}_{4} \mathrm{O}_{12}\right)$ ceramics [11757-27]

11757 OX Surface characteristics of polymer nanocomposites [11757-31] 